\title{
Environmental Geophysics: Buildings E5485, E5487, and E5489 Decommissioning - The "Ghost Town" Complex, Aberdeen Proving Ground, Maryland
}

by L.D. McGinnis, M.D. Thompson, and S.F. Miller

Reclamation Engineering and Geosciences Section, Energy Systems Division, Argonne National Laboratory, 9700 South Cass Avenue, Argonne, Illinois 60439 
This document is printed on recycled paper, with the exception of color reproductions. 


\section{DISCLAIMER}

This report was prepared as an account of work sponsored by an agency of the United States Government. Neither the United States Government nor any agency thereof, nor any of their employees, make any warranty, express or implied, or assumes any legal liability or responsibility for the accuracy, completeness, or usefulness of any information, apparatus, product, or process disclosed, or represents that its use would not infringe privately owned rights. Reference herein to any specific commercial product, process, or service by trade name, trademark, manufacturer, or otherwise does not necessarily constitute or imply its endorsement, recommendation, or favoring by the United States Government or any agency thereof. The views and opinions of authors expressed herein do not necessarily state or reflect those of the United States Government or any agency thereof. 


\section{DISCLAIMER}

Portions of this document may be illegible in electronic image products. Images are produced from the best available original document. 


\section{Preface}

This report is one of a series on environmental geophysical studies around perimeters of buildings in the Canal Creek area of the Edgewood section of Aberdeen Proving Ground. The series was initiated in 1991 at Building E5032, where techniques were evaluated and a design for the surveys was established. Studies continued in 1992, when surveys of Buildings E5190, E5282, E5375, E5440, E5476, E5481, E5974, and the Building E103 Dump were completed. Surveys and reports were done sequentially, by building number. For this reason, deeper insight into the magnetic, electrical, and radar-imagery characteristics of the Canal Creek area was gained with progressively increasing building numbers.

The building complex reported on here was initially surveyed in 1992 by using state-of-theart procedures and equipment available at that time; however, access along the western margin of the site was restricted because of the presence of a thick cover of tall reeds (phragmites). The site was cleared and resurveyed in August 1993 by using a new, continuously recording magnetometer and two electromagnetic instruments, the EM-31 and EM-61. Additional ground-penetrating-radar profiling was also completed in 1993. The new instrumentation and procedures significantly improved access capabilities, density of data coverage (by an order of magnitude), efficiency, and interpretive diagnostics. 


\section{Contents}

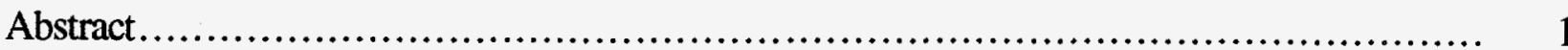

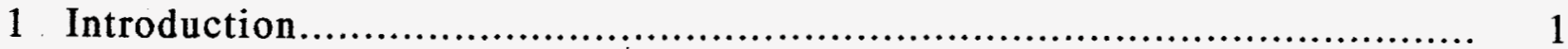

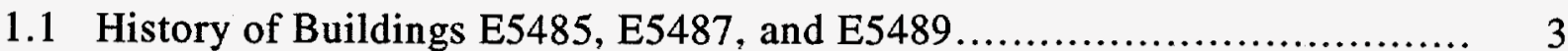

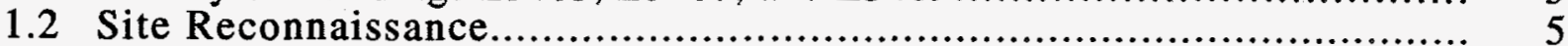

1.3 Geology and Physiographic Setting ............................................ 6

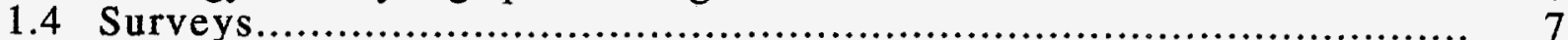

1.5 Survey Grid and Locations of Observations $\ldots \ldots \ldots \ldots \ldots \ldots \ldots \ldots \ldots \ldots \ldots \ldots \ldots$

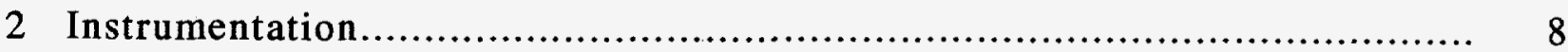

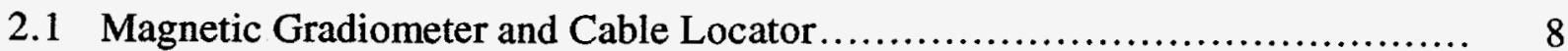

2.2 Magnetometers ................................................................. 8

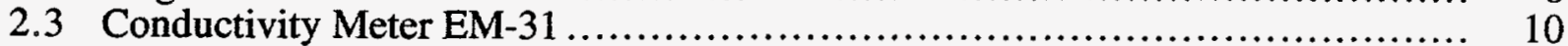

2.4 Time-Domain Millivolt Meter EM-61 ........................................ 10

2.5 Ground-Penetrating-Radar System................................................ 11

3 Geophysical Measurements and Surveys.................................... 12

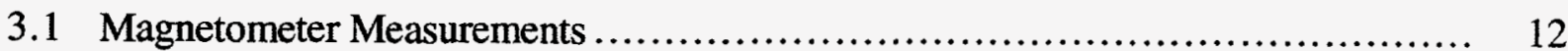

3.2 Horizontal Profiling Electromagnetic Measurements ............................ 12

3.2.1 Conductivity - EM-31 .............................................. 12

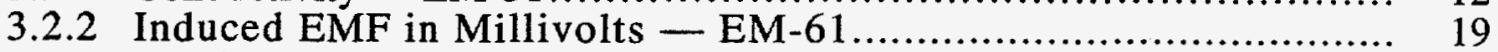

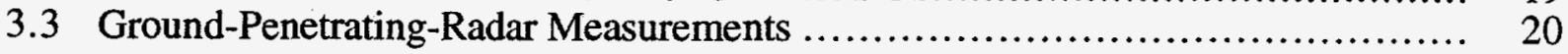

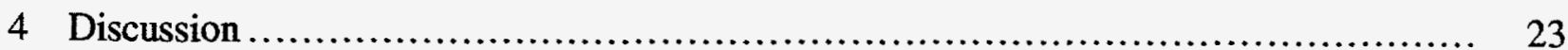

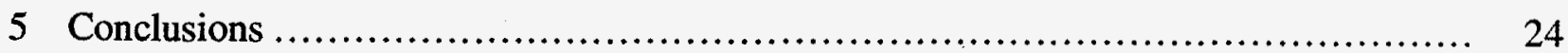

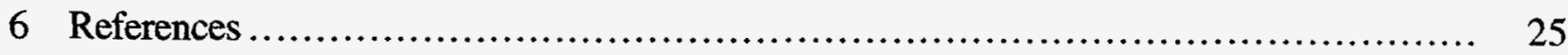

Appendix: Ground-Penetrating-Radar Line Coordinates ............................ 27

Table

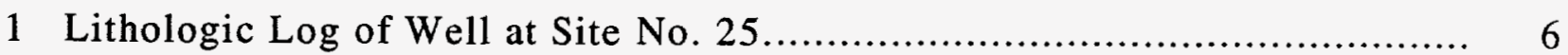

Figures

1 General Site Map of the Canal Creek Area, Aberdeen Proving

Ground, Maryland

2 General Location Map of Buildings E5485, E5487, and E5489 and Area Surveyed around the Buildings 


\section{Figures (Cont.)}

3 Total Intensity Magnetic Map of Buildings E5485, E5487, and E5489 Generated by Using the OMNI IV Magnetometer.

4 Total Intensity Magnetic Map of Buildings E5485, E5487, and E5489 Generated by Using the G8221 Magnetometer

5 Conductivity Map from EM-31 Measurements

6 Results of EM-61 Survey, in Millivolts of Induced Electrical Field

7 South-North Ground-Penetrating-Radar Profile for the Area East of Buildings E5485, E5487, and E5489 


\title{
Environmental Geophysics: \\ Buildings E5485, E5487, and E5489 Decommissioning - The "Ghost Town" Complex, Aberdeen Proving Ground, Maryland
}

by

L.D. McGinnis, M.D. Thompson, and S.F. Miller

\begin{abstract}
Buildings E5485, E5487, and E5489, referred to informally as the "Ghost Town" complex, are potentially contaminated sites in the Edgewood section of Aberdeen Proving Ground. Noninvasive geophysical surveys, including magnetics, EM-31, EM-61, and ground-penetrating radar, were conducted to assist a sampling and monitoring program prior to decommissioning and dismantling of the buildings. The buildings are located on a marginal wetland bordering the west branch of Canal Creek. The dominant geophysical signature in the "Ghost Town" complex is a pattern of northeast-southwest and northwest-southeast anomalies that appear to be associated with a trench/pipe/sewer system, documented by the presence of a manhole. Combinations of anomalies suggest that line sources include nonmetallic and ferromagnetic materials in trenches. On the basis of anomaly associations, the sewer lines probably rest in a trench, back-filled with conductive, amphibolitic, crushed rock. Where the sewer lines connect manholes or junctions with other lines, ferromagnetic materials are present. Isolated, unidentified magnetic anomalies litter the area around Building E5487, particularly to the north. Three small magnetic sources are located east of Building E5487.
\end{abstract}

\section{Introduction}

Aberdeen Proving Ground (APG), in the state of Maryland, is managing a comprehensive Installation Restoration Program involving more than 360 solid-waste-managing units contained within 13 study areas. The Edgewood Area of APG (Figure 1) is on the National Priority List, under the Comprehensive Environmental Response, Compensation, and Liability Act. APG has entered into an interagency agreement with the U.S. Environmental Protection Agency to address the listed areas.

A report by EAI Corporation (1989) included a list of 29 potentially contaminated buildings at APG. The buildings have been abandoned and operations have ceased, but processing equipment, sumps, drains, ventilation systems, and underground storage tanks remain. These appurtenances may contain liquid, solid, or vapor contaminants of unknown nature. Sixteen of the 


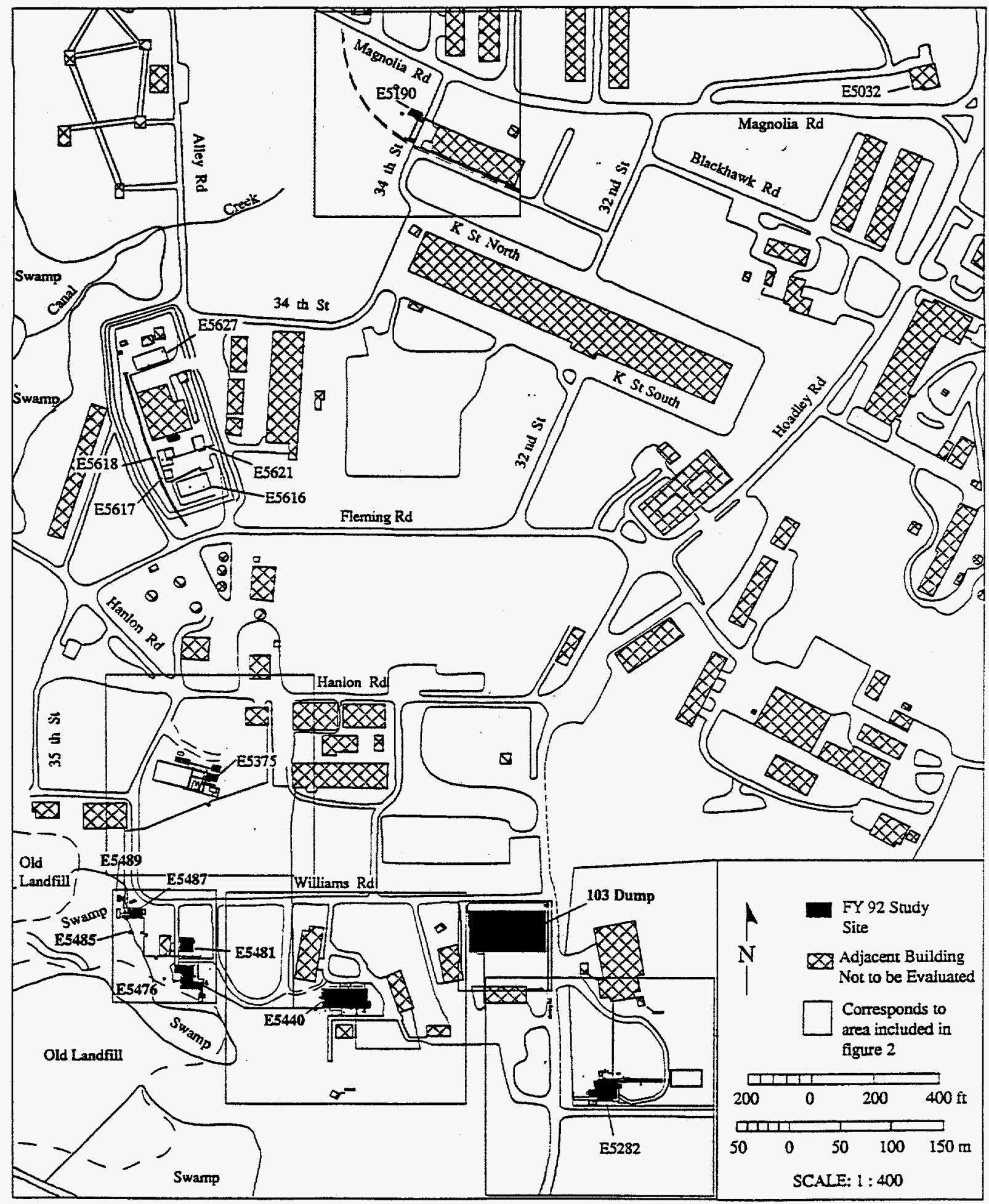

FIGURE 1 General Site Map of the Canal Creek Area, Aberdeen Proving Ground, Maryland 
buildings contain known contaminants, nine buildings contain unknown contaminants, and four buildings are potentially clean. The EAI report recommended that a sampling and monitoring program be established to verify contamination levels in and around each building. Most of the effort thus far has been in the Canal Creek area (Figure 1).

Thirteen of the potentially contaminated buildings, including Buildings E5485, E5487, and E5489, unofficially referred to as the "Ghost Town" complex (Figure 2), which is located at the southwest corner of Williams Road, are in the drainage basin of the west branch of Canal Creek and are potential sources of volatile organic compounds. The west branch of Canal Creek and its associated wetlands is one of the areas that require a source definition study, because there is an ongoing release of volatile organic compounds into the creek.

Aberdeen Proving Ground is proceeding with a program to decommission the buildings, which will eliminate the actual or potential release of contaminants into the environment. Argonne National Laboratory (ANL) has been assigned the task of developing a plan and scope of work for the proposed decommissioning. Argonne has determined that the first step in this decommissioning process, where it is technically feasible, should be a noninvasive geophysical survey around building exteriors (see Figure 2 for the general location map of the study area and dimensions of the area surveyed).

\subsection{History of Buildings E5485, E5487, and E5489}

According to a report on records examined by EAI Corporation (1989), Buildings E5485, E5487, and E5489 were constructed in 1921-22 as part of the experimental M-1 plant complex. The buildings in the complex are constructed of corrugated metal on concrete foundations measuring $12 \times 10 \mathrm{ft}, 43 \times 26 \mathrm{ft}$, and $21 \times 11 \mathrm{ft}$, respectively.

Building E5485 served as a fan house for agent operations until 1966 and for flammablematerials storage from 1966 to 1967 . Potential contaminants include petroleum, oil, and lubricants. Although no documentation outlining potential contaminants in this building was found, its status is listed as unknown because of its association with known agent operations. The building has been on the inactive list since 1967.

Building E5487 served as the main building of the experimental lewisite (M-1) plant. All reaction and distillation processes for the lewisite plant took place within Building E5487. Outside equipment consisted of a 500- $\mathrm{ft}^{3}$ gas holder, two concrete scrubbing towers, a compressed-air drying apparatus, and vacuum-pump line scrubbers, all of which were removed by the late 1960s. Production of lewisite began in June 1922 and continued until January 1926, at which time Building E5487 was placed on a standby mode. In the late 1940s and early 1950s, Building E5487 was modified for the development of chemical processes for manufacturing nerve agents. Reassignment of the building to an inactive status was initiated in 1967 , and it has remained inactive since then. 


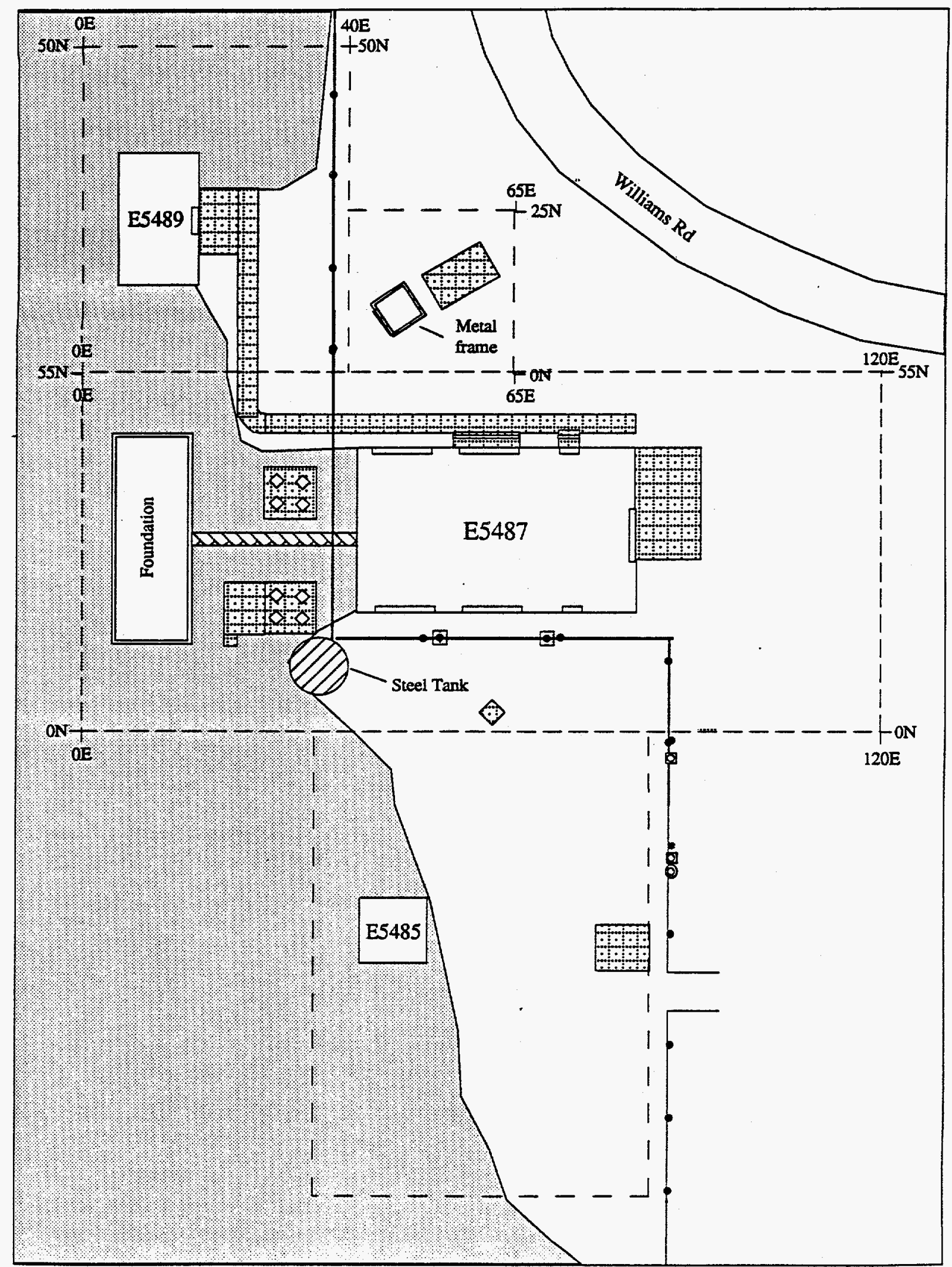

FIGURE 2 General Location Map of Buildings E5485, E5487, and E5489 and Area Surveyed around the Buildings 
Building E5489 was constructed for use as an office, first aid facility, laboratory, locker room, and change house. Reassignment of the building to an inactive status was initiated in 1967. It has remained inactive up to the present, although a note in the EAI report suggests that lewisite work continued in the building during the 1970s.

Wastes generated by the experimental lewisite plant included wastewater from the washing of reaction mixture, reaction mixture lost in flash distillation as a result of discharging unvaporized material, carbon waste from flash distillation and cyclone separation following the flash distillation, scrubbing charcoal in the vacuum lines associated with the distillation condenser receivers, tar from conversion of $\mathrm{M}-2$ and $\mathrm{M}-3$, residue from fractional distillation, wastewater from the caustic scrubbing towers, and bad batches that had to be discarded.

The method of disposal of solid wastes, including thick tars and contaminated charcoal, is not known (U.S. Army Environmental Hygiene Agency 1989), but the waste was probably either buried in an unknown location or dumped into the Canal Creek swamp. The contaminated charcoal was probably soaked in caustic solution before disposal (McQuaid and Muskopf 1922). The liquid wastes, including bad batches, were discharged to the sewer, which emptied into the Canal Creek swamp. These liquid wastes would have contained $M-1, M-2, M-3$, arsenic trichloride, aluminum, chloride, arsenic trioxide, and hydrolysis products of these compounds.

Little information is available concerning the sewer system for this complex, although it is likely that the plant had more than one sewer. McQuaid and Muskopf (1922) indicate that the plant was to have had a special sewer to which bad charges and certain other wastes would be discharged, and that it would include a caustic-solution tank located in the swamp west of the plant. Wright and Shaffer (1926) do not provide sewer details on drawings, but they do show a caustic tank west of the plant in a drawing and a photograph. The process of manufacturing agents was very inefficient, and over two-thirds of the arsenic was lost with the waste products. There was no sanitary sewer system before 1942, and any wastewater would have been discharged to the adjacent Canal Creek marsh. It is not known if the building's wastewater system was installed when the buildings were originally constructed.

\subsection{Site Reconnaissance}

The geophysical program design for Buildings E5485, E5487, and E5489 is based upon studies by ANL personnel made in the Edgewood Area of APG since 1991 (McGinnis and Miller 1991, McGinnis et al. 1992, McGinnis et al. 1992a and b, Miller et al. 1992a and b, and Thompson et al. 1992a and b). To enhance the initial evaluation, ANL personnel visited the site in November 1991 and inspected aerial photos. The buildings are located on level terrain adjacent to a wetland bordering the west branch of Canal Creek. The wetland is located immediately west and south of the buildings, where tall reeds (phragmites) restrict access to former structures peripheral to the buildings. 


\subsection{Geology and Physiographic Setting}

The site is contained in topographically low and flat terrain of the Coastal Plain physiographic province. The Canal Creek area is underlain by alluvial and estuarine sands, silts, and clays. A thin veneer of sediments of the Talbot Formation of Pleistocene age overlies unconsolidated sediments of the Potomac Group of Cretaceous age (Oliveros and Gernhardt 1988). The water table is less than five feet from the surface, and groundwater contains measurable levels of contaminants.

Lithologies at the site were determined from the sample study of a well (site \#25) drilled approximately $250 \mathrm{ft}$ southeast of Buildings E5485, E5487, and E5489. The descriptive log, given in Table 1, was part of a hydrogeologic study of the Canal Creek area performed by the U.S. Geological Survey (Oliveros and Gernhardt 1989).

TABLE 1 Lithologic Log of Well at Site No. 25

Descriptiona Depth (ft) Thickness (ft)

Soil zone, brown

0.1

0.1

Fill material: with brown, $[\mathrm{mL}-\mathrm{cL}]$ sand, gravel, rock fragments, sandstone, asphalt, metal

Sand, light brown-gray, [fL-mU]; with thin, black layer at top, and clayey, brown silt lense

Sand, multicolored, [fU-mU], wet; with irregular banding and gray, clayey sand lenses

10.8

1.8

Sand, light yellow-tan, [fU-cL], clean; with sparse light gray clay lenses

No sample

19.0

2.0

Sand and gravel, purple, orange, and $\tan [\mathrm{mU}-\mathrm{cU}]$, silty, micaceous clay

24.0

5.0

Silt, clayey, and sand, pink and orange-mottled, micaceous; sand [fL-fU], coarsening downward

29.0

5.0

a Codes enclosed in brackets at selected horizons refer to color designations as specified in the Munsell Soil Color Charts (1975).

Source: Oliveros and Gernhardt (1989). 
Facies represented include soils and a clayey fill material, which were followed by thin beds of varying stratigraphy (consisting primarily of sands) to a depth of $29 \mathrm{ft}$. Because initial construction probably involved considerable excavation and use of fill material, most of the shallow sediment at the site is reworked.

\subsection{Surveys}

Geophysical data were acquired during four days of field operations during the summer of 1992 to late 1993. On-site personal computers (both notebook and desktop), interactive software, field equipment designed specifically for APG building studies, and an all-terrain vehicle were used to expedite data acquisition and processing. Survey tools and techniques included magnetics, horizontal resistivity, conductivity (EM-31), induced EMF (EM-61), and ground-penetrating radar. The constant-electrode, horizontal resistivity survey was partially completed in 1992; however, access for that survey was limited because of overgrown phragmites in the wetlands, and the survey was therefore never completed.

\subsection{Survey Grid and Locations of Observations}

Before geophysical surveying, wooden stakes were placed at site corners, with the southwest corner serving as the zero coordinate. Positive coordinates are measured north and east of the zero coordinate. Buildings are oriented with outside walls aligned approximately northsouth and east-west. Geophysical profiles, spaced five feet apart, were oriented parallel with the sides of the buildings. 


\section{Instrumentation}

\subsection{Magnetic Gradiometer and Cable Locator}

The Schonstedt MAC-51B magnetic gradiometer and cable locator is a dual-mode instrument designed for detecting shallowly buried iron and steel objects and tracing underground cables and pipes. The system consists of a transmitter and a dual-function receiver designed to detect anomalous magnetic gradients. The MAC-51B is an audio device used only for rapidly detecting magnetic materials for further analysis with complementary instrumentation.

Maps or models are not constructed from observations made with this instrument because it is not a calibrated system, nor does it have the capability to digitally record data. Anomalies are identified by changes in sound amplitude and frequency and are marked on the ground surface before other surveys are initiated. If anomalies detected with the MAC-51B cannot be verified with the magnetometer (see Section 2.2), the anomaly is assumed to be insignificant.

Application of the MAC-51B in its receiver mode was the first geophysical operation after survey limits were established. A qualitative description of the site with $100 \%$ ground coverage is achieved by using the gradiometer, whereas the results obtained with other techniques, although more quantitative, are spatially limited to either single-point, survey-grid observations or continuous readings along spaced profiles.

\subsection{Magnetometers}

Magnetometer surveys were used for identifying ferromagnetic objects (such as tanks, drums, drain pipes, water lines, and small ferrous objects). The "Ghost Town" complex was surveyed twice in order to compare data quality obtained by using two instruments and two techniques. Internal software in both instruments permits downloading directly into an on-site computer.

The EDA OMNI IV proton-precession, total field magnetometer is read in a stationary mode. The sensing head can be held at any height above ground, depending on the depth and size of targets of interest. For the "Ghost Town" complex, the sensing head was held on the ground during readings. Station spacing varied, depending on anomaly wavelength and amplitude. In some areas, the distance between stations was as little as one foot.

The EG\&G Geometrics G-822L cesium-vapor magnetometer is also a total field instrument; however, observations can be made in the single-station, stationary mode, or while a person walks with the instrument in-hand, holding the sensing head held at some predetermined height above ground. For the "Ghost Town" complex, the sensing head was held approximately one foot above the ground surface, and measurements were made at a walking pace as data were 
acquired at rates of 10 readings per second. Average station spacing was $0.5 \mathrm{ft}$ along transects spaced $5 \mathrm{ft}$ apart.

Data quality is considerably greater when the OMNI IV is used; however, acquisition rates are much faster and, therefore, areal coverage is much greater when the G-822L is used. Data quality could be vastly improved with the G-822L, if data were read in the stationary mode. Both instruments are capable of resolving of anomalies to one nanotesla.

For a proper understanding of the magnetic field map acquired with the G-822L magnetometer, characteristics of magnetic fields and the instrument-specific recording properties of the magnetometer require some explanation. In areas where near-surface magnetic sources are common, information can be lost for two reasons: (1) the sampling interval is too large (undersampling) and entire sequences of paired peaks and troughs are not measured (skipped over), and (2) the magnetometer is not physically able to tune itself in a "high"-gradient area to obtain a reliable reading. In the second case, the magnetometer outputs a "no-data" value.

Loss of information from the first cause is minimized by slowing the walking pace and by decreasing the distance between profiles. Line spacing and sampling rate are dependent on the depth of interest of expected sources and the anomaly's wavelength. The sampling rate used at the "Ghost Town" complex yields approximately three to five samples per foot along a profile, which easily allows the detection of anomalies having wavelengths as small as $1.0 \mathrm{ft}$. Tie-line profiles are normally recorded in orthogonal directions in order to reduce the sampling bias perpendicular to profile trends.

Loss of information from the second cause is a hardware limitation and has serious effects on the quality of the final contoured magnetic anomaly maps. In this case, the magnetometer begins to "see" a magnetic peak or trough but quickly becomes untuned, outputting no-data values for the corresponding profile positions. At some later time, referred to by ANL staff as a "tuninglag," the magnetometer retunes and begins to output valid data. A data gap generally produces a single polarity anomaly, either negative or positive, that has a greater wavelength than the true anomaly.

The magnetic anomaly map constructed from G-822L data should be scrutinized carefully to correctly identify artifacts produced from either undersampling or from instrument limitations. This task primarily involves a detailed comparison of observed magnetic anomalies and surface features. Field notes describing the locations of observed metal debris, building and utility maps, and the magnetic anomaly map constructed from OMNI IV magnetometer data are incorporated into the interpretation phase to reduce the possibility of misidentifying magnetic features on the G-822L contoured map. The above discussion demonstrates why it is important to run profiles and tie lines in sets of orthogonal directions.

Because of their dipolar field, magnetic anomalies due to a source having a simple shape exhibit a characteristic shape, which consists of a positive magnetic peak and at least one negative magnetic trough. If iron-rich waste is buried in the northern hemisphere and becomes magnetized 
in the earth's field, a large positive anomaly will occur over a symmetrically shaped body with a weak negative offset to the north. The horizontal distance between the paired peak and trough is proportional to the depth of burial, size, and shape of the source; however, the amplitude of the anomaly is inversely proportional to the depth of burial. Metallic debris at, or just below, the ground surface produces strong, closely spaced magnetic peaks and troughs separated by highgradient areas.

As may be inferred from the above discussion, the sign of magnetic anomalies must be viewed with extreme caution because in a region of high gradients, the magnetometer becomes untuned and provides zero readings. Contouring software for the G-822L has been designed to bridge the zero gap with mean values taken from the last readable data along the profile. Thus, because of the bipolarity of magnetic anomalies (and the variability of gradients), it is possible for an isolated anomaly or a lineament to change from a positive to a negative feature along the trend. For the purposes reported here, the magnitude of the anomaly is unimportant; however, it is important to identify the feature as a lineament or as a "single" source.

Data sets from the OMNI IV and G-822L, contoured by using Surfer Version 4.0 software by Golden Software, Inc., Golden, Colorado (1991), were used to identify potential sources of contaminants and to distinguish them from background. The Surfer software was incorporated into the field-acquisition procedure so that daily map outputs were available for observation and interpretation. Following processing and gridding with Surfer software, anomalies were enhanced by using color-coded software - COLMX - developed by Thompson (1994).

\subsection{Conductivity Meter EM-31}

Mean conductivities were measured with the Geonics EM-31, an electrical induction meter that measures mean terrain conductivity to depths of approximately $20 \mathrm{ft}$. In EM profiling, electrical current flow is induced into the ground by a transmitter (induction coil), and a receiver measures the secondary magnetic field caused by the low-intensity "eddy" currents induced in the subsurface. Data were collected at 0.5-s intervals with the EM-31 and stored on the OMNI 720 data logger, which can simultaneously log Quad-phase, electrical conductivity data and In-phase, inductive data for metals, as well as store survey geometry. Data for this survey were recorded in the Quad phase only. Internal software permits downloading directly into an on-site computer. Conductivity contouring is incorporated into the field-acquisition procedure so that daily map outputs are available for observation and interpretation. Argonne staff used EM methods extensively in the Edgewood Area at Beach Point, J-Field, and the Pilot Plant.

\subsection{Time-Domain Millivolt Meter EM-61}

Field data were obtained in millivolts with an EM-61, a portable, time-domain, electrical induction instrument that transmits an electrical pulse into the ground and measures secondary induced voltages caused by metallic objects beneath the instrument. As a consequence of its coil 
arrangement, it is relatively insensitive to surface interference and is more sensitive to deeply buried metallic targets. Data are recorded on three channels, including a response from an upper coil $(\mathrm{CH} 1)$, lower coil $(\mathrm{CH} 2)$, and a coil difference $(\mathrm{CH} 3)$.

The coil difference channel equals $\mathrm{k} \times \mathrm{CH} 1-\mathrm{CH} 2$, where $\mathrm{k}$ is a multiplier in the software, which is normally equal to 1 . The lower coil, because of its spatial positioning, responds to signals from all depths within instrument range. For example, an anomaly of two millivolts would be detected by the lower coil from a 55-gal metal drum buried at a depth of about nine feet (Miro Bosnar, personal communication). Data recorded on the coil difference channel (CH3) are less sensitive to surficial debris. Contouring of data in millivolts is incorporated into the fieldacquisition procedure so that daily map outputs are available for observation and interpretation.

Data were collected at a rate of three readings per second and were stored on the OMNI 720 data logger. Internal software permits downloading directly into an on-site computer.

\subsection{Ground-Penetrating-Radar System}

Ground-penetrating-radar surveying and data processing were accomplished by using Geophysical Survey Systems, Inc., Radan I software (1987) and a model SIR-3 radar connected to a transceiver by a cable approximately $300 \mathrm{ft}$ long. Data were recorded on a digital audio tape to permit playback. The control unit/graphic recorder was located in the transport vehicle. A computer was located in a field office so that the radar operator could download data, check datatape quality, and do preliminary processing after a day's run.

Wave-velocity characteristics of near-surface materials were derived from known positions of buried objects. Internal calibration was run at least twice each day to ensure that the graphic record of the range setting was consistent. Studies conducted during the 1991 field season indicate wave velocities of $6-7 \mathrm{~ns} / \mathrm{ft}$ for near-surface sediment; however, conditions vary with the heterogeneity of the subsurface.

Ground-penetrating radar is the best method available for determining the depth and geometry of objects buried near the surface. The weakness of the method is its limited depth of exploration due to wave-propagating constraints imposed by the electrical properties of soils. The maximum depth of penetration with GPR at Buildings E5485, E5487, and E5489 was approximately $10 \mathrm{ft}$ below the ground surface. Depths are calculated from known travel times through materials normally found at Aberdeen. 


\section{Geophysical Measurements and Surveys}

\subsection{Magnetometer Measurements}

Maps of the total magnetic field and data points collected by using the two magnetometers described in Section 2.2 are shown in Figures 3 and 4. Figure 3 was constructed by using the OMNI IV station magnetometer, whereas the map in Figure 4 is based on G822L data. Individual data points are observed in Figure 3. Data points are so closely spaced in Figure 4 that they appear as solid lines along north-south transects spaced five feet apart.

Strong magnetic fields due to the corrugated iron walls of the buildings distort or obscure smaller local anomalies. Although some undulations in magnetic contours near the buildings are present, magnetic residual anomalies that might be produced by subsurface objects cannot be distinguished from anomalies having building sources.

Several unidentified magnetic objects are present around the buildings. Identified anomalies are due to buildings, overhead steam lines, concrete slabs containing reinforcement rods, Williams Road grade materials and a possible water main in the northeast corner of the surveyed area, a manhole cover $16 \mathrm{ft}$ south of Building E5485, a pile of concrete and construction debris north of Building E5487, and foundation materials from former sumps and towers west of Building E5487. Because this site is close to the wetlands, it is likely that several feet of highly magnetic amphibolitic fill were required to raise the grade of the surface on which the buildings and road were constructed. The amplitude of the magnetic anomalies spatially related with Williams Road appear far too great, however, to be caused by road grade alone. A water line buried adjacent to the road may also contribute to these anomalies.

A magnetic lineament trending north-south between $50 \mathrm{E}$ and $55 \mathrm{E}$, south of Building E5487, is caused by an overhead steam line (see Figure 4). The steam line and magnetic anomaly extend around the perimeter of the building on the south and west and continue north between $0 \mathrm{E}$ and $5 \mathrm{E}$ on the north side of Building E5487.

Three circular anomalies are clearly displayed in Figure 3 east and southeast of Building E5487. These anomalies are also observed in Figure 4, but they are far less prominent.

\subsection{Horizontal Profiling Electromagnetic Measurements}

\subsubsection{Conductivity - EM-31}

Horizontal profiling with the EM-31 provides a map of weighted, mean conductivity from the surface to a depth of $20 \mathrm{ft}$ around the "Ghost Town" complex (Figure 5). EM-31 data were 


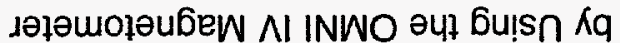

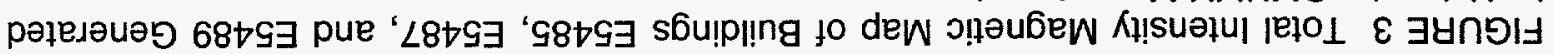

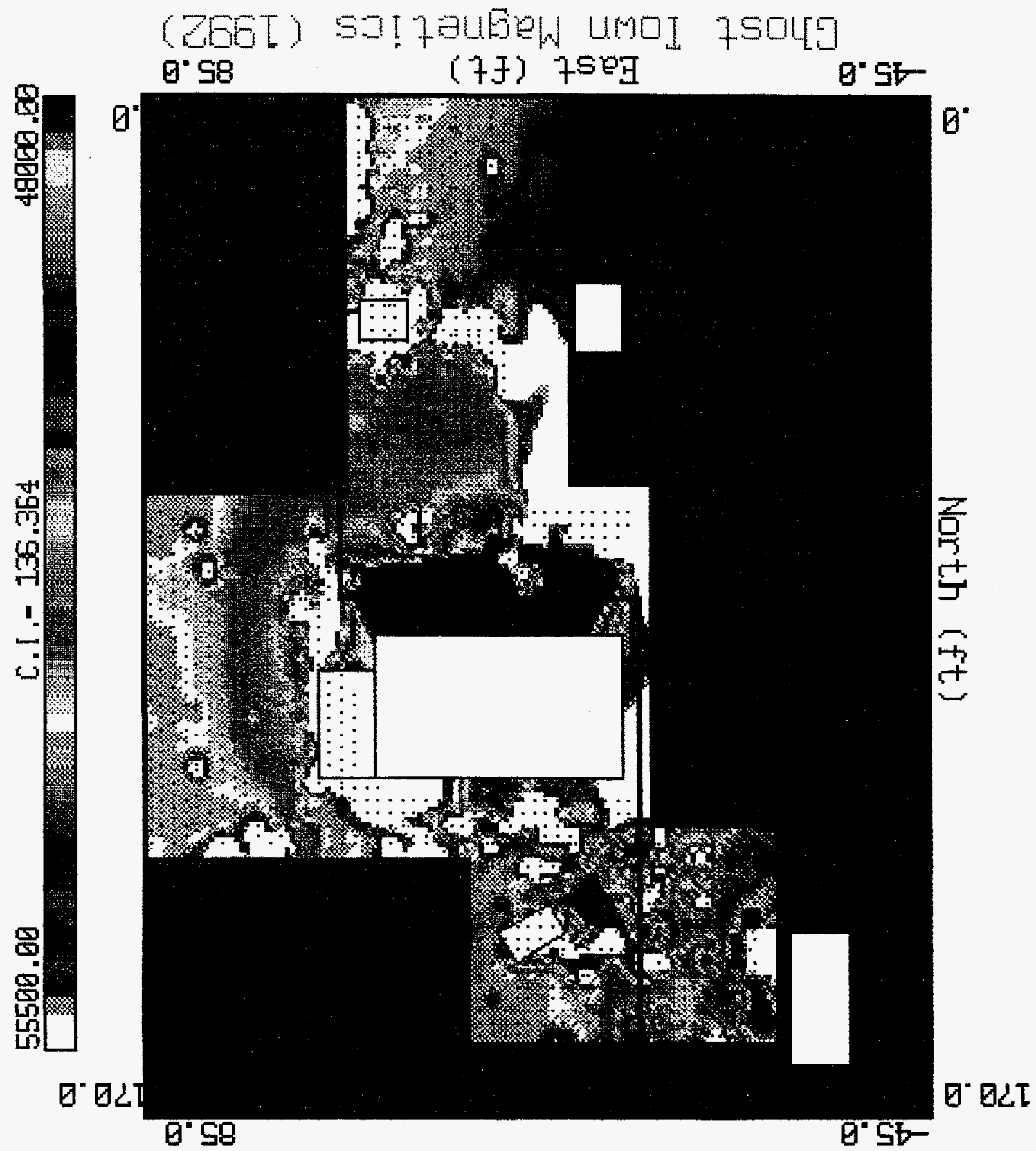




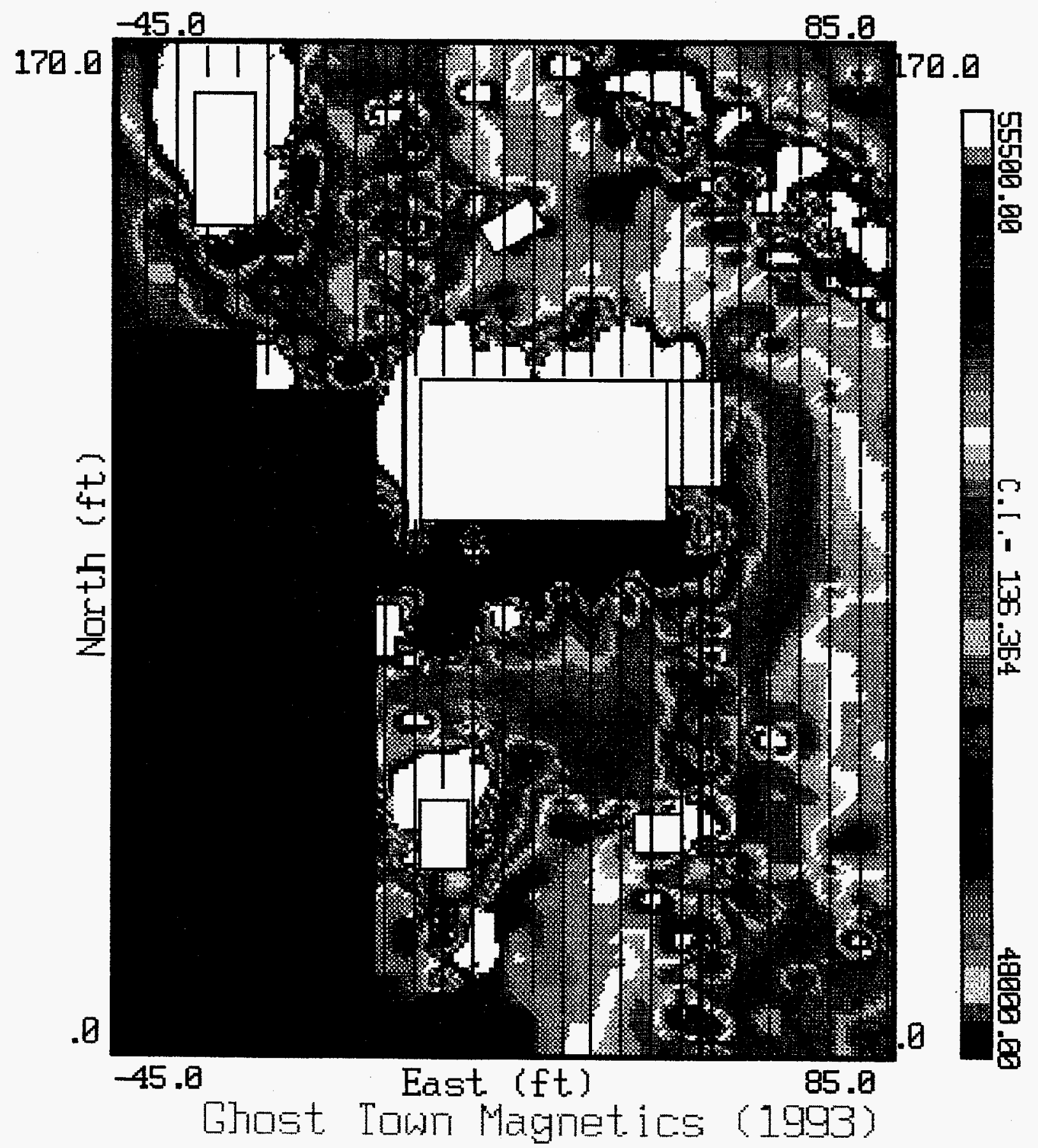

FIGURE 4 Total Intensity Magnetic Map of Buildings E5485, E5487, and E5489 Generated by Using the G822! Magnetometer 


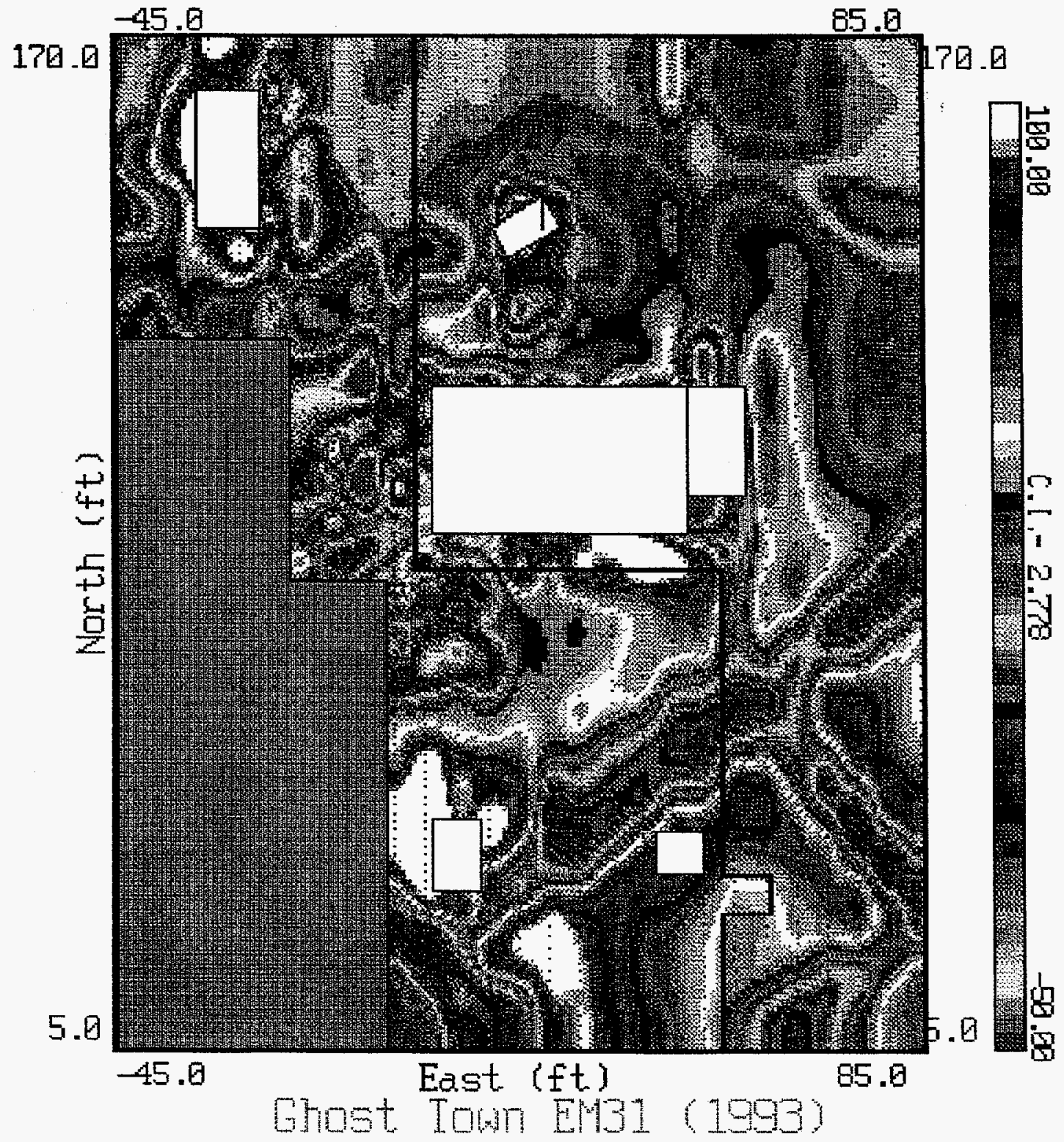

FIGURE 5 Conductivity Map from EM-31 Measurements 
acquired at a 0.5 -s sampling rate along the same transects traversed with the magnetometer. Some field distortion is observed in close proximity to the buildings; however, prominent linear anomalies are associated with subsurface sources (with anthropogenic origins) found throughout the surveyed area.

From north to south, conductive anomalies include the following:

1. A positive conductivity anomaly centered near the road at approximately $170 \mathrm{~N}-47 \mathrm{E}$ has an amplitude too large to be associated with simple road fill. The anomaly is thought to be partially caused by an underground water main.

2. A prominent lineament extending northward from the northwest corner of E5489 could be a building anomaly.

3. A north-south positive lineament on the east edge of Building E5487 (and possibly joining a positive lineament trending southwest toward Building E5485) is unexplained.

4. Positive anomalies are in a complex association of anomalies in the southeast quadrant of the mapped area. These anomalies are separated by a T-shaped negative. The entire complex of positives and negatives may be an artifact of the EM31, which is caused by separation of the EM source and receiver as they cross over linear features.

Beginning on the north margin of the surveyed area, conductivity minima include the following:

1. A closed, elongate conductivity low over concrete rubble north of Building E5487.

2. Poorly defined negative features caused by edge effects near the concrete pit behind Building E5487.

3. A prominent negative anomaly south of the southwest corner of Building E5487.

4. A prominent T-shaped anomaly trending northeast from the southeast corner of Building E5485. The top of the $T$ trends northeast, while the base of the T trends southeast.

5. Rectilinear negatives in the southeast quadrant described in item No. 4, above, in the section on conductive anomalies. 
The EM-31 map, by itself, is inconclusive relative to identification of subsurface lineaments in the southern half of the map. The T-shaped minimum enters the wetland $5-10 \mathrm{ft}$ south of Building E5485, where it intersects with another northwest-trending lineament. The manhole, located $16 \mathrm{ft}$ south of Building E5485, is associated with the lineament trending northwest.

\subsubsection{Induced EMF in Millivolts - EM-61}

A map constructed from EM-61 $\mathrm{CH} 2$ data (lower coil), which responds to all signals from the surface to approximately nine feet, is shown in Figure 6. Anomalies and their sources are characterized as follows:

1. An anomaly cluster in the north-central area is caused by a waste-debris pile north of Building E5489.

2. Anomalies of approximately $244 \mathrm{mV}$ in the northeast quadrant have sources that are associated with road fill and possibly a water main.

3. In the east-central zone, a prominent, low-intensity, positive lineament, averaging about $90 \mathrm{mV}$ above background, trends northeast from an anomalous area immediately south of Building E5485. The lineament increases in intensity from northeast to southwest.

4. Northwest-southeast lineaments converge with northeast-southwest lineaments in the southeast quadrant. Some of the anomalies are attributable to overhead steam lines. It is possible that the increase in intensity to the southwest along the northeast-southwest lineament is caused by utility convergence. The northeast-southwest lineament is of interest because it also outlines the anomalous trend identified by the EM-31. This trend was not seen by the magnetometer, which suggests that it is nonferromagnetic, but it is slightly conductive. Because the northeast-southwest trend does not contain a strong remanent magnetic signature (but is slightly conductive) and has a low amplitude-induced voltage, it probably outlines a trench that is backfilled with crushed gravel, which consists of crystalline rock high in magnetite, such as the amphibolites used for local construction materials. The trench probably contains a nonmagnetic, but slightly conductive, clay tile. Southeast-trending lineaments in the southeast quadrant may indicate a second trench intersecting the northeast lineament.

5. EM-61 anomalies in the southwest quadrant are associated with underground utilities. A large, circular, high-intensity anomaly south of Building E5485 is caused by a manhole $16 \mathrm{ft}$ south of Building E5485. Other geophysical lineaments described above appear to terminate at the manhole. 


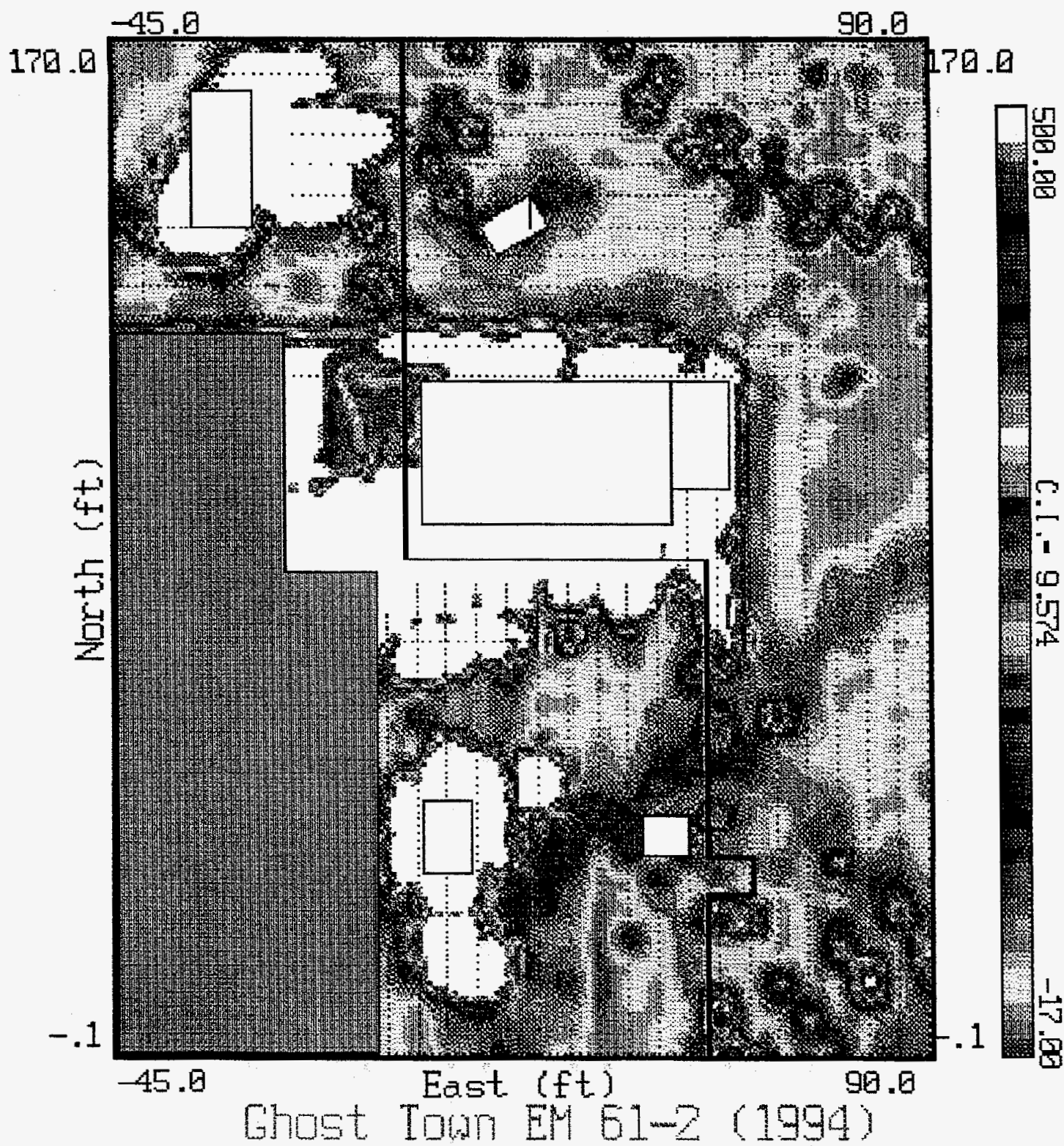

FIGURE 6 Results of EM-61 (Coil 2) Survey, in Millivolts of Induced Electrical Field

\subsection{Ground-Penetrating-Radar Measurements}

Coordinates of GPR lines are shown in Appendix B. The lines are numbered in sequence, along with the beginning and ending positions relative to the grid survey. Before the production lines were run for the survey, replicate runs were made over the same line to determine which of the three transceivers the $80-, 300-$, or $500-\mathrm{MHz}$ antenna was best suited for the study of the terrain surrounding the site. The transceiver providing the best penetration and resolution of buried objects was the $300-\mathrm{MHz}$ unit. Different range settings were also tested over the same transect to determine the optimum resolution and depth of penetration. A range setting of $90 \mathrm{~ns}$ was used for the entire survey; the scan rate was 16 scans per second. 
Without verification by another technique or by passing the antenna over an object of known depth, characteristics of radar anomalies may only be inferred. However, where anomalies are also seen with magnetic or resistivity profiling, a diagnostic interpretation of the radar anomaly is possible. Good penetration was observed over most of the site, with resolution to about eight feet below the ground surface.

Figure 7 shows GPR profiles collected along a south-to-north traverse east of the building. The vertical scale is shown on the right side of the profile, whereas the horizontal scale is defined by broken vertical marker lines at $10-\mathrm{ft}$ intervals.

GPR anomalies that were detected around Buildings E5485, E5487, and E5489 are associated with underground utilities, road construction, grade raising, and other construction activities. The only significant finding around Buildings E5485, E5487, and E5489 are the anomalies caused by probable sewer lines and trenches. Figure 6 illustrates the twin GPR anomalies caused by this feature. 


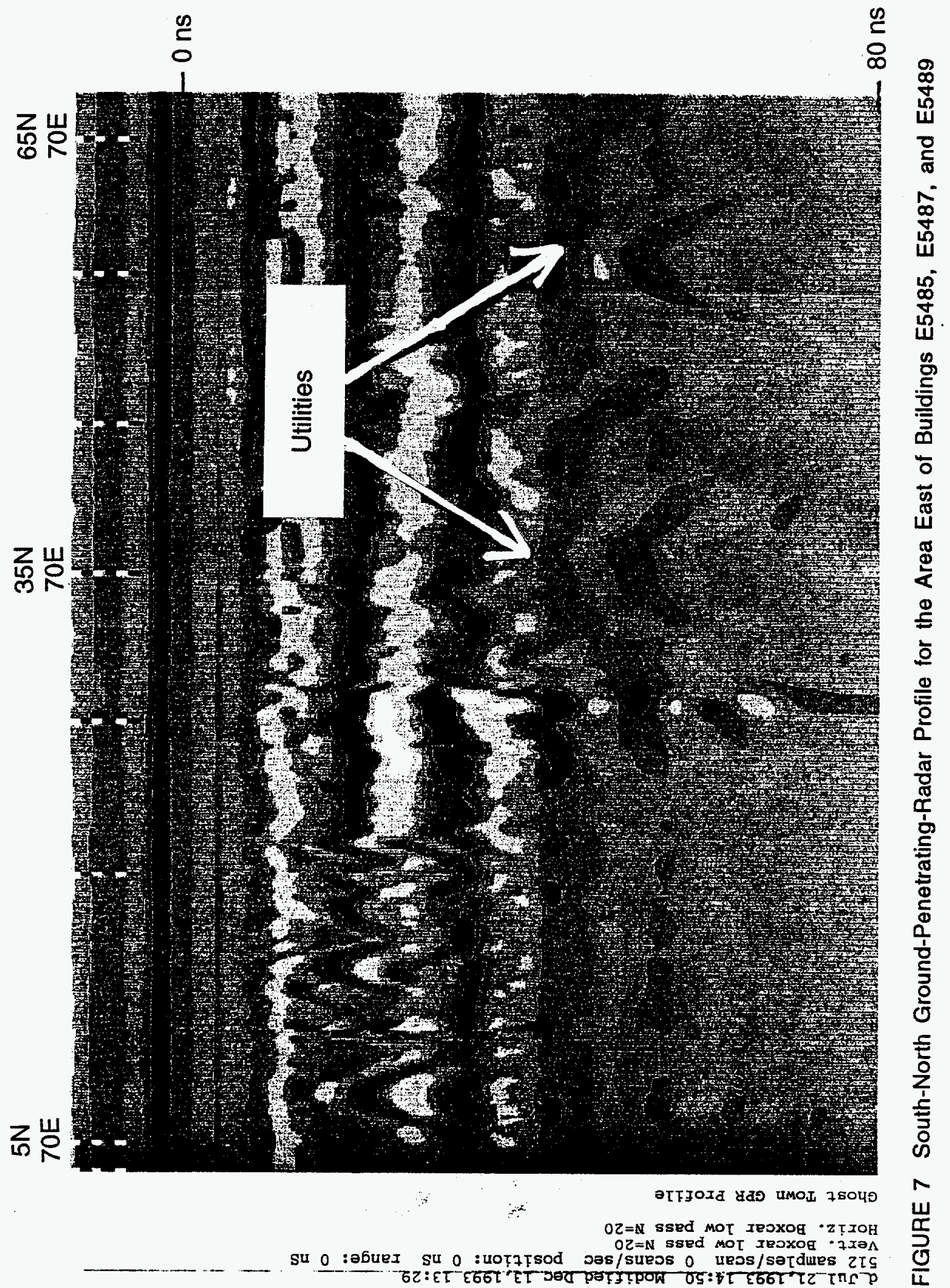




\section{Discussion}

The close proximity of dense marsh grass and phragmites immediately west of the "Ghost Town" complex limited the western boundary of the survey area to approximately $10 \mathrm{ft}$ from the western walls of the buildings. In addition, a concrete pit and remnants of building equipment lying on the ground surface adjacent to the western side of Building E5487 reduced the value of data in terms of subsurface interpretations. Thus, the identification and distribution of underground pipes, trenches, and sewer lines could not be ascertained after they entered the wetland.

The dominant geophysical signature in the "Ghost Town" complex is an orthogonalgridded pattern of northeast-southwest and northwest-southeast anomalies in the east and south of the surveyed area. Included in the pattern is a T-shaped EM-31 lineament in the southeast quadrant. Although the pattern is best displayed with the EM-31, it is also partially displayed with the EM-61 and magnetometer, particularly where anomaly amplitudes increase toward the southwest. Therefore, the source of the central $\mathrm{T}$-anomaly lineament, at least in its northeast limits, is probably a clay or concrete sewer line. The T-shaped anomaly terminates in the southwest corner at a junction with another lineament trending northwest-southeast.

The gridded pattern of lineaments includes a manhole cover surrounded by a concrete slab $16 \mathrm{ft}$ south of the southeast corner of Building E5485. The manhole area is associated with prominent magnetic and EM-61 positive anomalies and is located south of the southwest termination of the T-shaped EM-31 low-conductivity and EM-61 lineaments (see Figures 5 and 6), suggesting that the anomaly sources include nonmetallic sewer lines and ferromagnetic sections. On the basis of the anomaly associations, the sewer lines probably rest in a trench, back-filled with conductive, amphibolitic, crushed rock. Where they connect manholes or junctions with other lines, ferromagnetic materials are present.

The orientation and location of the sewer-line system indicate that it probably drains part of the Canal Creek area, including Buildings E5487 and E5485, and empties into the wetland bordering the West Branch of Canal Creek. Magnetic and both EM-31 and EM-61 anomalies link up with the system from the southeast corner of Building E5487.

The axial negative anomaly on the EM-31 map, on both sections of the T, bisects an unexplained, broad positive anomaly. The trench dug for sewer lines may also contain additional pipes.

Magnetic lineaments are also associated with an aboveground overhead steam line (Figure 4) and Williams Road (Figures 3 and 4). Because of the intensity of the anomaly trending parallel with Williams Road, the road anomaly may be enhanced by a buried water main.

Isolated unidentified magnetic anomalies litter the area around Building E5487, particularly to the north. Three small magnetic sources are located east of Building E5487. 


\section{Conclusions}

Site geophysical surveys around Buildings E5485, E5487, and E5489, the "Ghost Town" complex, yield the following conclusions:

1. A prominent northeast-southwest geophysical lineament crossing the complex, which may represent a sewer-line system, is associated with a manhole located $16 \mathrm{ft}$ south of the southeast corner of Building E5485. The manhole is located in a grid of orthogonal geophysical lineaments seen in a combination of magnetic, EM-31, and EM-61 anomalies. An anomaly observed on all geophysical maps extends south from the east side of Building E5487 and connects with the prominent northeast-southwest lineament.

2. High-amplitude magnetic and EM-61 anomalies along Williams Road suggest that in addition to amphibolitic road fill, the road may be underlain by a ferromagnetic water main pipe.

3. Unexplained magnetic point sources are randomly distributed throughout the "Ghost Town" complex.

4. Three or four lineaments in the southeast quadrant, indicating buried metallic objects, are observed with the EM-61. Lineaments trending northwestsoutheast are unexplained in the southeast quadrant of the survey area. 


\section{References}

EAI Corporation, 1989, Historical Records Search and Site Survey of Edgewood Area Buildings, Final Report, prepared for U.S. Army Chemical Research, Development, and Engineering Center, Aberdeen Proving Ground, Md., under contract No. DAA15-87-D0021.

Geophysical Survey Systems, Inc., 1987, Operations Manual for Subsurface Interface Radar (SIR System-3).

McGinnis, L.D., and S.F. Miller, 1991, Interim Progress Report - Geophysics: Building E5032 Decommissioning, Aberdeen Proving Ground, Argonne National Laboratory report ANL/ESD/TM-20, Argonne, Ill.

McGinnis, L.D., et al., 1992, Interim Progress Report - Geophysics: Building E5440 Decommissioning, Aberdeen Proving Ground, Argonne National Laboratory report ANL/ESD/TM-42, Argonne, Ill.

McGinnis, M.G., et al., 1992a, Interim Progress Report - Geophysics: Building E5375 Decommissioning, Aberdeen Proving Ground, Argonne National Laboratory report ANL/ESD/TM-37, Argonne, Ill.

McGinnis, M.G., et al., 1992b, Interim Progress Report - Geophysics: Building E5974 and E5978 Decommissioning, Aberdeen Proving Ground, Argonne National Laboratory report ANL/ESD/TM-47, Argonne, Ill.

McQuaid, H.S., and M.A. Muskopf, 1922, M1 Operating Procedure, EACD-140, Chemical Division, Edgewood Arsenal, Aberdeen Proving Ground, Md., April.

Miller, S.F., et al., 1992a, Interim Progress Report - Geophysics: Building E5476 Decommissioning, Aberdeen Proving Ground, Argonne National Laboratory report ANL/ESD/TM-43, Argonne, III.

Miller, S.F., et al., 1992b, Interim Progress Report - Geophysics: Building E5190 Decommissioning, Aberdeen Proving Ground, Argonne National Laboratory report ANL/ESD/TM-33, Argonne, Ill.

Munsell Soil Color Charts, 1975, Macbeth, a division of Kollmorgen Corp., Baltimore, Md.

Oliveros, J.P., and P. Gernhardt, 1989, Hydrogeologic Data for the Canal Creek Area, Aberdeen Proving Ground, Maryland, April 1986-March 1988, U.S. Geological Survey Open-File Report 89-387. 
Thompson, M.D., 1994, COLMX Software, Unpublished.

Thompson, M.D., et al., 1992a, Interim Progress Report - Geophysics: Building E5282 Decommissioning, Aberdeen Proving Ground, Argonne National Laboratory report ANL/ESD/TM-36, Argonne, Ill.

Thompson, M.D., et al., 1992b, Interim Progress Report - Geophysics: Building E5481 Decommissioning, Aberdeen Proving Ground, Argonne National Laboratory report ANL/ESD/TM-44, Argonne, $\mathrm{Ill}$.

U.S. Army Environmental Hygiene Agency (AEHA), 1989, RCRA Facility Assessment Report, Edgewood Area, Aberdeen Proving Ground, Maryland.

Wright, H.V., and H.G. Shaffer, 1926, Development of Manufacturing Process for M1, EACD-367, Chemical Division, Edgewood Arsenal, Aberdeen Proving Ground, March 1. 
Appendix:

Ground-Penetrating-Radar Line Coordinates 
TABLE A.1 Ground-Penetrating-Radar

Profiles: Buildings E5485, 5487, and 5489

\begin{tabular}{|c|c|c|c|c|}
\hline \multirow[b]{2}{*}{ Line No. } & \multicolumn{2}{|c|}{ Start Coordinates } & \multicolumn{2}{|c|}{ End Coordinates } \\
\hline & East & North & East & North \\
\hline 1 & 85 & 5 & 85 & 170 \\
\hline 2 & 80 & 5 & 80 & 170 \\
\hline 3 & 75 & 5 & 75 & 170 \\
\hline 4 & 70 & 5 & 70 & 170 \\
\hline 5 & 65 & 5 & 65 & 170 \\
\hline 6 & 60 & 5 & 60 & 170 \\
\hline 7 & 55 & 5 & 55 & 170 \\
\hline 8 & 50 & 5 & 50 & 170 \\
\hline 9 & 45 & 5 & 45 & 85 \\
\hline 10 & 40 & 5 & 40 & 85 \\
\hline 11 & 35 & 5 & 35 & 85 \\
\hline 12 & 30 & 5 & 30 & 85 \\
\hline 13 & 25 & 5 & 25 & 85 \\
\hline 14 & 20 & 5 & 20 & 85 \\
\hline 15 & 17.5 & 5 & 17.5 & 85 \\
\hline 16 & 15.0 & 5 & 15.0 & 30 \\
\hline 17 & 10 & 5 & 10.0 & 30 \\
\hline 18 & 5 & 5 & 5 & 30 \\
\hline 19 & 0 & 5 & 0 & 75 \\
\hline 20 & -45 & 170 & +25 & 170 \\
\hline 21 & -45 & 165 & +25 & 165 \\
\hline 22 & -45 & 125 & +25 & 125 \\
\hline 23 & -45 & 130 & +25 & 130 \\
\hline 24 & -45 & 135 & +25 & 135 \\
\hline 25 & -45 & 125 & -45 & $170 \mathrm{~N}$ \\
\hline 26 & -40 & 125 & -40 & $170 \mathrm{~N}$ \\
\hline 27 & -35 & 130 & -30 & $170 \mathrm{~N}$ \\
\hline
\end{tabular}

